\title{
Pengaruh Ekstrak Kulit dan Jus Buah Delima Putih (Punica granatum L.) Terhadap Titer Antibodi Ayam Kampung Super yang Divaksin Newcastle Disease
}

\section{(EFFECT OF WHITE POMEGRANATE (Punica granatum l.) SKIN EXTRACT AND JUICE ON KAMPUNG SUPER CHICKEN ANTIBODY TITER VACCINATED BY NEWCASTLE DISEASE)}

\author{
Anlisia Rahmawati ${ }^{1 *}$, Nanik Sianita Wijaya ${ }^{2}$, Muhammad Thohawi Elziyad Purnama ${ }^{3}$, \\ Jola Rahmahani ${ }^{2}$, Aditya Yudhana ${ }^{4}$, Maya Nurwartanti Yunita ${ }^{5}$ \\ ${ }^{1}$ Bachelor of Veterinary Medicine, \\ ${ }^{2}$ Department of Veterinary Microbiology, \\ ${ }^{3}$ Department of Veterinary Anatomy, \\ ${ }^{4}$ Department of Parasitology, \\ ${ }^{5}$ Department of Pathology, \\ Faculty of Veterinary Medicine, Universitas Airlangga, \\ UNAIR C-Campus Mulyorejo, Surabaya, Jawa Timur, Indonesia, 60115 \\ Telp. (031)5993016, Fax. (031)5993015 \\ *Corresponding author: anlisia.rahmawati-2014@fkh.unair.ac.id
}

\begin{abstract}
Abstrak
Penelitian ini bertujuan untuk mengetahui pengaruh ekstrak kulit dan buah delima terhadap titer antibodi ayam kampung super yang divaksin Newcastle Disease. Penelitian ini menggunakan Rancangan Acak Lengkap (RAL). Sampel terdiri dari 40 ekor ayam kampung super yang dibagi acak menjadi 4 kelompok perlakuan. Perlakuan yang diberikan adalah K- tidak divaksin. K+, P1 dan P2 divaksin dengan ND Lasota. Kemudian setelah titer antibodi ayam rendah, $\mathrm{K}$ - diberikan aquadest steril, $\mathrm{K}+$ diberikan CMC-Na 0,5 \%, P1 diberikan ekstrak kulit delima (200 mg/kg BB), P2 diberikan jus buah delima (3 ml/kg BB). Sampel berupa serum di uji $\mathrm{HI}$ untuk mengetahui titer antibodi. Hasil rata-rata jumlah titer antibodi uji pertama pada K- yaitu $(\log 2) 1,10^{\mathrm{a}} \pm 0,994$, pada $\mathrm{K}+$ yaitu $(\log 2) 4,60^{\mathrm{b}} \pm 0,699$, pada P1 yaitu $(\log 2) 5,90^{\mathrm{c}} \pm 0,876$, dan pada $\mathrm{P} 2$ yaitu $(\log 2) 7,20^{\mathrm{d}} \pm 0,632$. Dan pada uji kedua pada K- yaitu $(\log 2) 0,20^{\mathrm{a}} \pm 0,422$, pada K+ yaitu $(\log 2) 4,90^{\mathrm{b}} \pm 0,876$, pada P1 yaitu $(\log 2) 6,50^{\mathrm{c}} \pm 0,707$, dan pada $\mathrm{P} 2$ yaitu $(\log 2) 8,00^{\mathrm{d}} \pm 0,816$. Ada perbedaan yang nyata mengenai peningkatan titer antibodi pada masing-masing perlakuan. Berdasarkan hasil dapat disimpulkan bahwa ada pengaruh ekstrak kulit dan jus buah delima terhadap titer antibodi ayam kampung super yang divaksin Newcastle Disease. Penelitian disarankan untuk menggunakan jus buah delima karena lebih efektif.
\end{abstract}

Kata kunci: buah Delima Putih. Punica granatum L., Newcastle Disease, titer antibodi

\section{Abstract}

This study aimed to determine the effect of peel extract and pomegranate juice on antibody titer of kampung super chicken vaccinated by Newcastle Disease. This study used a completely random design (CRD). The sample consisted of 40 kampung super chicken were randomized into four treatment groups. $K$ - treatments were not vaccinated. $K+, P 1$ and $P 2$ vaccinated with ND Lasota. Then, after antibody titer is low, $K$ - was given with sterile distilled water, $K+$ given with $0.5 \%$ CMC-Na, Pl given peel extract $(200 \mathrm{mg} / \mathrm{kg} \mathrm{BB}), P 2$ given with pomegranate juice $(3 \mathrm{ml} / \mathrm{kg} \mathrm{BB})$. Samples of serum in HI test to determine antibody titer. Result obtained the average number of antibody titers in the first test for the $K$ - is $1,10^{a}, K+i s 4,60^{b}$, in P1 is 5,90', and P2 is 7,20d. On the second test of antibody titer of $K$ - is $0,20^{a}, K+$ is 4,90 , in P1 is 6,50', and P2 is 8,00d. There was significant differences regarding an increase of antibody titer in each treatment. Based on the results it can be concluded that there was an influence of peel extract and pomegranate juice to kampung super chicken antibody titers vaccinated by Newcastle Disease. It is suggested to used pomegranate juice because it is more effective to increase antibody.

Key words: white pomegranate, Punica granatum L., Newcastle Disease, antibody titers 


\section{PENDAHULUAN}

Newcastle Disease (ND) merupakan salah satu penyakit infeksius yang penting dalam industri perunggasan. Newcastle Disease dilaporkan sebagai penyakit endemis sejak tahun 1926 yang terjadi di beberapa negara di dunia termasuk Indonesia. Newcastle Disease menyebabkan kerugian yang sangat signifikan terhadap perekonomian di bidang perunggasan karena angka morbiditas dan angka mortalitas mencapai $100 \%$. Peternakan unggas yang terserang penyakit Newcastle Disease juga berpengaruh terhadap penurunan produksi unggas (Ojok dan Brown, 1996; Aldous et al., 2003; Leuck et al., 2004).

Penyakit ND yang disebabkan oleh avian paramyxovirus dapat menginfeksi lebih dari 200 spesies unggas tetapi tingkat keparahan bervariasi tergantung dari inang dan strain virus. Strain velogenik tipe Asia sering menimbulkan wabah di Indonesia. Strain lentogenik (La Sota, B1, F) dan strain mesogenik (Komarov, Mukteswar, Roakin) dipakai untuk pembuatan vaksin. Ayam mengalami tingkat kepekaan yang paling parah dibandingkan dengan unggas lainnya yaitu kalkun, itik, angsa, dan entok (Tabbu, 2000). Respon kekebalan seluler dan kekebalan humoral berperan penting dalam melawan infeksi avian paramyxovirus (Hewajuli dan Dharmayanti, 2011).

Obat yang efektif untuk pengobatan ayam yang sudah terserang penyakit Newcastle Disease sampai saat ini masih belum ada. Pencegahan penyakit Newcastle Disease lebih efektif jika dilakukan dengan cara pemberian vaksin (Polana dan Fadilah, 2005). Beberapa jenis tanaman obat dapat menjadi alternatif pencegahan. Tanaman obat di Indonesia pernah dilaporkan memiliki potensi sebagai imunostimulant yakni buah delima putih (Punica granatum L.).

Delima putih (Punica granatum L.) diketahui mempunyai aktivitas antioksidan yang kuat yakni fenolik, flavonoid dan tanin. Kandungan tanin, alkaloid, glikosida, flavonoid dan senyawa fenolik sebagai antioksidan dalam jus, kulit, dan fraksi biji delima putih
(Hajimahmoodi et al., 2013). Delima putih mempunyai antioksidan kuat yang lebih unggul dari anggur merah dan teh hijau. (Mohammad dan Kashani, 2012).

Buah Delima putih (Punica granatum L.) dapat digunakan sebagai imunostimulant. Kandungan yang terdapat pada buah, biji, dan kulit dapat meningkatkan aktivitas imun. Peningkatan aktivitas imun dapat merangsang respon imun humoral yang dibuktikan dengan penghambatan serta meningkatkan migrasi leukosit dan meningkatkan titer antibodi. (Ross et al. 2001). Buah delima putih dapat merangsang produksi imunoglobulin dalam sel-sel pada limpa tikus dan dapat meningkatkan fungsi sel B in vivo (Yamasaki et al. 2006).

\section{METODE PENELITIAN}

\section{Alat dan Bahan Penelitian}

Sampel penelitian ini adalah 40 ekor ayam kampung super jantan. Alat yang digunakan untuk ekstraksi: corong butchner, labu buchner, kertas saring, vacuum pump, rotary evaporator, vial, toples kaca, pengaduk, alumunium foil. Alat yang digunakan untuk keperluan di Kandang: Kandang ayam, kardus, trash bag, tempat pakan, tempat minum, sekam padi, dan gayung. Alat yang digunakan untuk ambil darah dan Uji Hi: spuit $1 \mathrm{cc}$, spuit $3 \mathrm{cc}$, needle $27 \mathrm{G}$, microtube, rak microtube, sentrifuse, waterbath, gelas ukur, baker glass, kulkas, mikropipet $25 \mu \mathrm{l}$ dan $50 \mu \mathrm{l}$, mikroplate bentuk (V), yellowtip, baskom, label nama, pinset dan gunting.

Bahan yang digunakan dalam penelitian ini adalah buah delima, serbuk kulit delima putih, Ayam kampung super, pakan konsentrat, air minum, alas kandang (erbuk padi dan kardus). Vaksin ND live (La Sota), etanol 96\%, NaCl fisiologis, antigen ND 4 HA unit, dan eritrosit ayam $0,5 \%$.

\section{Perlakuan}

Ayam diadaptasikan dengan lingkungan selama 4 minggu sambil menunggu titer antibodi rendah, setelah titer antibodi rendah diberi perlakuan selama 35 hari atau 5 minggu. 
Vaksinasi dengan ND La Sota dilakukan pada ayam kelompok $\mathrm{K}+, \mathrm{P} 1$, dan $\mathrm{P} 2$ pada musculus pectoralis. Vaksinasi dilakukan dua kali. Vaksinasi pertama dilakukan pada ayam umur 5 minggu, dan vaksinasi kedua dilakukan pada ayam umur 7 minggu. Perlakuan yang dilakukan menurut Sibi dan Varghese (2014) adalah: (K-) Tidak divaksin ND+diberi aquadest steril; $(\mathrm{K}+)$ Divaksin ND+diberi $\mathrm{CMC} \mathrm{Na} 0,5 \%$; (P1) Divaksin ND+diberi ekstrak kulit delima putih dengan dosis 200 mg/kg BB; dan (P2) Divaksin $\mathrm{ND}+$ diberi jus buah delima putih dengan dosis 3 $\mathrm{ml} / \mathrm{kg} \mathrm{BB}$.

\section{Pembuatan Ekstrak}

Pembuatan ekstrak kulit delima dapat dilakukan dengan cara memasukkan serbuk kulit delima putih sebanyak 500 gram ke dalam toples kaca dan dituangi etanol $96 \%$ sebanyak $\pm 1,5$ liter sampai terendam semua serta dilakukan pengadukan 3 jam sekali dalam waktu 2x24 jam. Larutan ekstrak disaring dengan corong buchner dengan menggunakan vacuum pump. Kemudian dipindahkan dalam rotary evaporator dengan suhu $60^{\circ} \mathrm{C}$ sampai didapatkan cairan ekstrak menjadi kental dan berwarna kecoklatan. Ekstrak kental didiamkan pada suhu ruang selama \pm 2 minggu untuk menguapkan etanol yang terdapat pada ekstrak (Dewi, 2010).

Pembuatan Jus Buah Delima dapat dilakukan dengan cara mengupas kulitnya kemudian mencuci buah dengan air mengalir. Selanjutnya buah dimasukkan dalam juicer dan nyalakan. Biji akan terpisah secara otomatis dengan buah. Encerkan jus buah dengan aquadest steril dengan perbandingan 1:3. Kemudian simpan dalam kulkas.

\section{Pengambilan Serum Darah}

Pengambilan darah untuk memperoleh serum guna uji $\mathrm{HI}$ dilakukan dengan mengambil darah menggunakan spuit secara aseptic lalu darah yang ada didalam spuit tersebut kemudian dimasukkan dalam microtube dan didiamkan hingga terjadi pemisahan. Apabila serum darah yang didapatkan kurang jernih maka dilakukan sentrifuge dengan kecepatan 1500 rpm selama 10 menit. Selanjutnya serum diinktivasi menggunakan waterbath dengan suhu $56^{\circ} \mathrm{C}$ selama 30 menit. Serum dapat disimpan pada suhu $4^{\circ} \mathrm{C}$ atau $-20^{\circ} \mathrm{C}$.

Suspensi eritrosit dengan konsentrasi $0,5 \%$ didapatkan dari darah ayam diambil dari vena brachialis secukupnya $( \pm 3 \quad \mathrm{ml})$ kemudian dimasukkan ke dalam tabung reaksi yang telah diisi dengan EDTA. Darah tersebut kamudian di sentrifuse selama 10 menit dengan kecepatan $1500 \mathrm{rpm}$, setelah disentrifuse kemudian supernatannya dibuang dan disisakan endapannya. Selanjutnya pencucian terhadap endapan dengan $\mathrm{NaCl}$ fisiologis dan disentrifuse kembali selama 10 menit. Setelah terjadi endapan, supernatan dibuang lagi dan dilakukan pencucian lagi dengan $\mathrm{NaCl}$ fisiologis diulang sampai 3 kali seperti cara yang ada di atas. Untuk mendapatkan suspensi eritrosit 0,5\% sebanyak $100 \mathrm{ml}$, maka endapan eritrosit murni diambil $0,5 \mathrm{ml}$ kemudian di tambahkan $\mathrm{NaCl}$ fisologis $99,5 \mathrm{ml}$.

\section{Uji Hemaglutinasi (HA)}

Cara titrasi antigen 4 HA Unit sebagai berikut: 1) Mengisi lubang mikroplate dengan 25 $\mu \mathrm{NaCl}$ fisiologis mulai dari lubang 1-5 pada baris I dan II (titrasi duplikat); 2) Mengisi lubang 1 baris I dan II dengan antigen; 3) Mencampurkan antigen dan $\mathrm{NaCl}$ fisiologis pada lubang 1 dengan cara hisap-tiup, kemudian pindahkan ke lubang berikutnya. Demikian seterusnya sampai dengan lubang 4 dan lubang 5 digunakan sebagai kontrol eritrosit (tanpa antigen); 4) Mengisi semua lubang dengan eritrosit ayam 0,5\% dengan volume $50 \mu \mathrm{l} .5$ ) Inkubasi pada suhu kamar selama 30 menit, kemudian dibaca titernya. Bila antigen ND 4 HAU maka hemaglutinasi terjadi pada lubang nomer 1 dan 2. (Ernawati et al., 2013).

\section{Uji Hemaglutinasi Inhibisi (HI)}

Metode dari Uji Hemaglutinasi Inhibisi (HI) mikroteknik adalah sebagai berikut: 1) Pada lubang nomer 1 sampai dengan lubang nomer 10 dan 12 dari microplate diisi $\mathrm{NaCl}$ fisiologis sebanyak $25 \mu \mathrm{l}$; 2) Pada lubang 1 ditambahkan serum yang akan diuji sebanyak $25 \mu 1$; 3) Micropipet di masukkan ke lubang nomor 1 
untuk dilakukan mixing, kemudian dilakukan pengenceran secara seri dengan memindahkan micropipet $25 \mu$ ldari lubang 1 ke lubang 2 lalu dilakukan pencampuran dan dipindahkan lagi ke lubang ke 3 dan seterusnya sampai lubang nomer 10 ; 4) Pada lubang nomer 12 digunakan sebagai kontrol serum; 5) Lubang 1 sampai 10 diisi antigen 4 HAU sebanyak $25 \mu$ lalu di inkubasi selama 30 menit pada suhu kamar; 6) Pada lubang 1 sampai lubang 10 dan 12 ditambahkan eritrosit ayam $0,5 \%$ sebanyak $50 \mu \mathrm{l}$. kemudian microplate digoyangkan secara perlahan lalu dibiarkan selama 30 menit atau sampai kontrol eritrosit dapat dibaca. Hambatan hemaglutinasi sempurna (100\%) adalah terjadinya pengendapan eritrosit pada dasar lubang microplate yang terlihat seperti pada kontrol. Titer antiserum adalah kebalikan dari pengenceran tertinggi antiserum yang masih mampu manghambat aglutinasi dengan sempurna (Ernawati et al., 2013).

\section{HASIL DAN PEMBAHASAN}

Uji HI dilakukan untuk analisa statistik kemudian dilakukan uji dengan Analysis of Variance satu arah (one way ANOVA). Jika terdapat perbedaan yang nyata dilanjutkan dengan uji Duncan. Hasil disajikan dalam tabel 1 .

Tabel 1. Hasil analisa statistik rata-rata titer antibodi ayam umur 7 dan 9 minggu

\begin{tabular}{ccc}
\hline \multirow{2}{*}{ Perlakuan } & \multicolumn{2}{c}{ Titer Antibodi $(\log$ 2) Mean \pm SD } \\
\cline { 2 - 3 } & $\mathbf{7}$ minggu & 9 minggu \\
\hline K- & $1,10^{\mathrm{a}} \pm 0,994$ & $0,20^{\mathrm{a}} \pm 0,422$ \\
$\mathrm{~K}+$ & $4,60^{\mathrm{b}} \pm 0,699$ & $4,90^{\mathrm{b}} \pm 0,876$ \\
$\mathrm{P} 1$ & $5,90^{\mathrm{c}} \pm 0,876$ & $6,50^{\mathrm{c}} \pm 0,707$ \\
P2 & $7,20^{\mathrm{d}} \pm 0,632$ & $8,00^{\mathrm{d}} \pm 0,816$ \\
\hline
\end{tabular}

Keterangan: Superskrip yang berbeda pada kolom yang sama menunjukkan adanya perbedaan yang nyata antar perlakuan $(\mathrm{p}<0,05)$

Deteksi titer antibodi yang digunakan dalam penelitian ini menggunakan uji HI. Prinsip uji HI adalah terdapat hambatan aglutinasi sel darah merah oleh virus akibat terikatnya virus dengan antibodi spesifik. Oleh sebab itu, uji HI hanya bisa digunakan untuk virus yang dapat mengaglutinasi sel darah merah. Virus paramyxoviridae merupakan virus penyebab penyakit Newcastle Disease yang mempunyai sifat dapat mengaglutinasi sel darah merah. (Ernawati et al., 2013).

Senyawa khas pada buah delima putih (Punica granatum L.) yakni ellagitannin, granatin A, dan granatin B. Granatin merupakan salah satu bentuk senyawa dari elligatannin yang terdapat dalam buah delima putih (Punica granatum $L$.). Granatin terbagi menjadi 2 yakni granatin A dan granatin B. Granatin A terdapat pada kulit buah dan granatin B terdapat dalam buah delima (Romeo et al, 2015).

Mekanisme pembentukan imun dalam tubuh ayam dilakukan oleh sistem imun humoral yakni limfosit B (sel B). Sel B berkembang dalam bursa fabrisius, yang timbul dari epitel kloaka. Setelah matang, sel B bergerak ke alat-alat seperti limpa, kelenjar limpoid dan tonsil. Atas pengaruh antigen melalui sel $\mathrm{T}$, sel $\mathrm{B}$ berproliferasi dan berdiferensiasi menjadi sel plasma yang mampu membentuk dan melepas Ig dengan spesifitas yang sama seperti reseptor yang ada pada permukaan sel prekusornya. Sebagian sel yang dibentuk akan kembali ke dalam fase istirahat. Sel B yang matang sebagai sel B memori dapat memberikan respon imun yang lebih cepat. Sel B merupakan 5-15\% dari jumlah seluruh limfosit dalam sirkulasi. Dungsi utamanya ialah memproduksi antibodi (Tizard, 1988).

Pada ayam yang tidak divaksin (K-) mengalami penurunan pada uji $\mathrm{HI}$ pada umur 9 minggu (2 minggu seteah vaksinasi kedua). $\mathrm{K}$ merupakan ayam kampung super yang tidak divaksin dan diberi aquadest steril. Penurunan titer antibodi yang terjadi pada kelompok K- 
disebabkan oleh menurunnya titer antibodi maternal dalam tubuh ayam. Hal ini sesuai dengan pernyataan Indriani dan Darmiento (2000) yakni antibodi asal induk ayam (maternal) akan turun secara linier seiring bertambahnya umur ayam.

Pengaruh ekstrak kulit dan jus buah delima putih terhadap titer antibodi sesuai dengan pendapat Sibi dan Varghese, (2014) yang menyatakan bahwa penelitian secara laboratoris kandungan senyawa flavonoid dapat meningkatkan proliferasi dan diferensiasi limfosit B dan limfosit T.

Ekstrak Kulit dan buah delima putih memiliki kandungan yang sama tetapi berbeda pada persentase kandungannya. Pada uji aktivitas antioksidan (DPPH) pada buah delima putih menyatakan bahwa kandungan pada buah delima putih jauh lebih baik daripada ekstrak kulit delima putih. Hal ini sesuai dengan pernyataaan Mootal dan Shaker (2011). Sehingga titer antibodi pada jus buah delima putih memiliki titer antibodi yang lebih tinggi daripada ekstrak kulit delima putih.

Faktor pendukung yang dapat membantu peningkatan titer antibodi diantaranya yaitu pemenuhan kebutuhan pakan, sistem pemeliharaan yang baik, vaksinasi, dan faktor lingkungan. Faktor-faktor tersebut merupakan kesatuan sistem. Apabila salah satu faktor terabaikan maka penanganan terhadap faktor yang lain tidak dapat memberikan hasil yang maksimal (Chopra dan Robert, 2001).

\section{KESIMPULAN}

Ekstrak kulit dan jus buah delima putih (Punica granatum L.) dapat meningkatkan titer antibodi ayam kampung super yang divaksin ND. Terdapat perbedaan yang nyata antara pemberian ekstrak kulit dan jus buah delima putih (Punica granatum L.) terhadap peningkatan titer antibodi ayam kampung super yang divaksin ND.

UCAPAN TERIMA KASIH
Peneliti mengucapkan terima kasih kepada kedua orang tua yang telah membiayai penelitian dan Prodi Kedokteran Hewan PSDKU Banyuwangi Universitas Airlangga atas fasilitas penelitian.

\section{DAFTAR PUSTAKA}

Aldous, E.W., J.K. Myno, J. Bank dan D.J. Alexander. 2003. A Molecular Epidemiological Study of Avian Paramyxovirus Tipe 1 (Newcastle Disease Virus) Isolates by Phylogenetic Analysis of A Partial Nucleotide Sequence of The Fusion Protein Gene. Avian pathology, 32(3): 239-257.

Chopra, I. dan M. Robert. 2001. Tetracycline Antibiotic : mode in action, application, moleculer biology, and epidemiology of bacterial resistances. Microbiol Mol Biol rev, 62: 232-260.

Dewi, F.K. 2010. Aktivitas Antibakteri Ekstrak Etanol Buah Mengkudu (Morinda citrifolia Linnaeus) Terhadap Bakteri Pembusuk Daging Segar. Surakarta: Fakultas MIPA, Universitas Sebelas Maret Surakarta.

Ernawati, R., A.P. Rahardjo, N. Sianita, J. Rahmahani, F.A. Rantam, dan Suwarno. 2013. Petunjuk Praktikum Pemeriksaan Virologik dan Serologik. Laboratorium Virologi dan Imunologi. Fakultas Kedokteran Hewan. Universitas Airlangga. Hal.31.

Hajimahmoodi, M., G. Moghaddam, A.M. Ranjbar, H. Khazani, N. Sadeghi, M.R. Oveisi, B. Jannat. 2013. Total Phenolic, Flavonoids, Tannin Content and Antioxidant Power of Some Iranian Pomegranate Flower Cultivars (Punica granatum L.). Am J Plant Sci, 4(09): 1815.

Hewajuli, D.A. dan N.L.P.I. Dharmayanti. 2011. Patogenitas Virus Newcastle Disease Pada 
Ayam. Bogor: Balai Besar Penelitian Veteriner. Wartazoa, 21(2): 72-80.

Indriani, R. Dan Darminto. 2000. Penyakit Infectious Bronchitis pada ayam dan cara mengendalikannya. Wartazoa, 5(2): 65-72.

Leuck, D., M. Haley, and D. Harvey. 2004. US 2003 and 2004 Livestock and Poultry Trade Influenced by Animal Disease and Trade Restrictions. US Department of Agriculture, Economic Research Service.

Mohammad, S.M., H.H. Kashani. 2012. Chemical composition of the plant Punica granatum L. (Pomegranate) and its effect on heart and cancer. J Med Plants Res, 6(40): 5306-5310.

Motaal, A.A. and S. Shaker. 2011. Anticancer and Antioxidant Activities of Standardized Whole Fruit, Pulp, and Peel Extracts of Egyptian Pomegranate. $J$ Open Conf Proceed, 2: 41-44.

Ojok, L. and C. Brown. 1996. An Immunohistochemical Study of the Pathogenesis of Virulent Viscerotropic Newcastle Disease in Chickens. J Comp Pathol, 115: 221-227.

Polana, A. dan R. Fadilah. 2005. Aneka Penyakit pada Ayam dan Cara Mengatasinya.
Bandung : Agro Media Pustaka. Hal.14.

Romeo, F.V., G. Ballistreri, S. Fabroni, S. Pangallo, M.G.L.D. Nicosia, L. Schena, and P. Rapisarda. 2015. Chemical characterization of different sumac and pomegranate extracts effective against Botrytis cinerea rots. Molecules, 20(7): 11941-11958.

Ross, R.G., S. Selvasubramanian, S. Jayasundar. 2001. Immunomodulatory activity of Punica granatum in rabbits-a preliminary study. $J$ Ethnopharmacol, 78(1): 85-87.

Sibi, P.I. and P. Varghese. 2014. Evaluation of In Vivo Immunomodulatory Activity of Punica Granatum Linn. India. $J$ Res Ayuverda Pharm, 5(2): 175-178.

Tabbu, C.R. 2000. Penyakit Ayam dan Penanggulangannya; Penyakit Bakterial, Mikal dan Viral. Volume I. Kanisius. Yogyakarta. Hal.232-244.

Tizard. 1988. Pengantar Imunologi Veteriner. Airlangga University Press Surabaya. Hal.89.

Yamasaki M., T. Kitagawa, and N. Koyanagi. 2006. Dietary Effect of Pomegranate Seed Oil on Immune Function and Lipid Metabolism in Mice. Nutrition, 22(1): 54-59. 